\title{
Work-Family Interface of Hospitality Industry in Malaysia: The Moderating Effects of Religiosity
}

\author{
Adriel K. S. Sim ${ }^{1} \&$ Sopian Bujang ${ }^{2}$ \\ ${ }^{1}$ School of Business, Curtin University, Sarawak Campus, Malaysia \\ ${ }^{2}$ Faculty of Cognitive Sciences \& Human Development, University Malaysia Sarawak, Malaysia \\ Correspondence: Adriel K. S. Sim, School of Business, Curtin University, Sarawak Campus, Malaysia. E-mail: \\ adriel.sim@curtin.edu.my
}

Received: March 1, 2012

Accepted: April 19, $2012 \quad$ Published: July 1, 2012

doi:10.5539/ass.v8n8p139

URL: http://dx.doi.org/10.5539/ass.v8n8p139

\begin{abstract}
This paper highlighted the lack of studies that examined the relationship between work-family interface and job and family satisfaction in hospitality industry. Based on review of past research on work-family studies and related constructs, this paper discussed the development of propositions linking work-family conflict, work-family enrichment, job and family satisfaction. Next, the development of proposition to test the possible moderating effects of religiosity will also be discussed. The major theoretical, empirical and practical contributions of this study will also be highlighted and discussed. The conceptual model presented shed light on work-family research which could be used for future research in this area.
\end{abstract}

Keywords: work-family conflict, work-family enrichment, hospitality industry, job satisfaction, family satisfaction

\section{Introducation}

Work and family are the domains of greatest importance to individuals. Both work and family roles can have meaningful impact on psychological well being and satisfaction (Schwartzberg \& Dytell, 1996; Kossek \& Ozeki, 1998; Schultheiss, 2006). The activities within work and family domains generally take up more time and energy than most other roles. The interface between work and family roles has generated intense inquiry among researchers who seek to understand the potential for both realms of adult life to create job satisfaction, family satisfaction and life satisfaction (Near, Smith, Rice, \& Hunt, 1984; Rice, McFarlin, Hunt, \& Near, 1985; Duxbury \& Higgins, 1991; Friedman \& Greenhaus, 2000).

A review of the literature shows that work and family issues, which are increasingly popular topics in contemporary organizational research, have received little attention in hospitality and tourism journals (Mulvaney, O'Neill, Cleveland, \& Crouter, 2007). The hospitality industry is very worthy for research as it is now the second largest contributors in terms of Malaysia's foreign earnings towards national income. With the changes of demographic shift in the workforce and the revolutionary changes in the organization as well as increased numbers of individuals with significant responsibilities both at home and at work, work-family study has thus become a concern of practical as well as theoretical significance. The issue is particularly urgent and important for hospitality industry in Malaysia due to the characteristics of the industry and the vital contribution of this industry to the development of the nation.

This study is thus to develop and test a research model that examines the relationship between work-family interface and job and family satisfaction and the moderating role of religiosity on these relationships in the context of hotel industry. While the extent literature has explored models addressing work-family conflict and work-family enrichment separately, little is known about how all these variables fit together as part of a more comprehensive model. By creating a model of work-family interface, relevant variables can be examined in greater detail.

\section{Work-family Studies in Hospitality Industry}

Many hotel positions, both managerial and line require long and irregular hours because hotels are open 24 hours daily. Having too few employees present can result in poor guest service, frustrated and overworked employees, 
and lost sales. Due to the demands of being a "24/7" industry, hotel companies often have norms that encourage employees, especially managers, to work as many hours as possible. Many work schedules in the hospitality sector are countercyclical to the work schedules of most other industries. The busiest shifts in hotels and restaurants are most frequent when most other people are off from work during weekends and public holidays. Not only are employees often required to keep long and irregular hours, but there is an expectation that employees, especially managers, will be physically present as much as possible, regardless of the actual necessity of being there. Munck (2001) named this the "culture of face time" (p.125). This norm is also reinforced by the widespread norm in the hotel sector that employees must "pay their dues" (p.367) to get ahead (Eder and Lundberg, 1990).

The hotel sector also has a norm of frequent relocation, particularly for managers (Kennedy and Fulford 1999). While relocation is a major part of career advancement in this business, it can contribute to conflict in that it is very disruptive and stressful to families, requiring transitions to new schools, neighborhoods, and employers for working spouses (Lu and Cooper 1990; Martin 1999). In contrast, some studies mentioned that relocation does not necessarily have only negative impact but can offer employees and their families opportunities and resources that can enhance family life, such as a chance for families to experience living in and learning about new cultures (Eby and Allen 1998; Martin 1999). Much research would be required in work-family studies especially in the context of hospitality industry as the challenges of this industry have historically faced with work-family conflict (Dermody and Holloway 1998; Stalcup and Pearson 2001). Hoteliers may be able to achieve strategic advantage by effectively addressing work-family issues.

\section{Statement of the Problem}

Most research on work-family has been conducted in Western settings over the past many decades. Due to more extensive research in Western context, many Western governments and corporations have policies to support individuals in their aspirations to be successful in both their career and family lives. They also tend to focus more on gender equality, and thus uphold the idea that both men and women should have equal responsibility for their families and equal opportunities in employment.

Over the past two to three decades, there is an emerging body of literature that has begun to examine work-family interface in Asian countries. The empirical and theoretical literature purports that there are cultural values and norms common to many Asian cultures. One widely accepted distinction of Asian cultures is its collectivistic worldview (Hofstede, 2001; Yang et. al, 2000). Other traditional Asian culture values that are aligned with the collectivistic worldview include interpersonal harmony, the paramount importance of family, respect to parents and elders. In many Asian countries, resources for work-family initiatives by government and corporations are scarce particularly in less developing countries. In the nations of the east, it is less likely to find strong beliefs about gender equality.

Therefore, it is an open question on the applicability of Western work-family research to men and women in Asia context. The difference in terms of culture makes work-family study context specific. Due to the rising number of multinational firms that employ individual from various parts of the world (Cascio, 2003); it is important to have more work and family research in Asia context in order to have better understanding of work-family interface in this region.

In addition, work and family issues are intricately related to cultural beliefs, values, and norms (Schein, 1984; Lobel, 1991). Many cultural beliefs are associated strongly with religious beliefs. In an Asian context, particularly of South East Asia numerous religious groups can be found in the region. Many western literature on religiosity reported that higher levels of religiosity lower levels of depression, higher level of positive affect, less emotional distress and greater life satisfaction (Ellison, Gay, \& Glass, 1989; Levin, Chatters, \& Taylor, 1995; Pargament, Koeing, \& Perez, 2000; Fiala, Bjorck, \& Gorsuch, 2002; Cole, Hopkins, Tisak, Steel, \& Carr, 2008). Many researches have shown that religious involvement is associated with attitudes about family and shape how men and women invest their time and their roles as husband or wife and father or mother (Sherkat \& Ellison, 1999; Wilcox, Chaves, \& Franz, 2004).

In Malaysia, Noor (1999) studied on employed women found that those who were more religious tended to experience lesser work family conflict. In addition, Abdullah (1994) in his study on the Malaysian workforce argued that most Malaysians identify with a particular religion and among the Malays, there is also the need to interpret work according to the religion of Islam. In a more recent study by Noor (2008) on a sample of married Malay muslim women, it was found that Islam, as all other religions, is associated with well-being because it provides a guide on how to live one's life and is positively associated with life satisfaction and negatively with psychological distress. 
Amin and Alam (2008) suggested that religion exerts a significant influence on human behavior. They argued that as the world economy becomes integrated, policy makers must take into considerations of the effects of religion on human behavior. Furthermore, Malaysia is a country that emphasis very much on religion as the "Rukun Negara" or National Principles of Malaysia stated the first principle is "Kepercayaan kepada Tuhan" or "to believe in God". The country is made official to be Muslim country. Other religions are tolerated and the individual's right to the freedom of worship is stated in the country's constitution. Abdullah (1996) also stressed that Malaysians are religious. In addition, the government also encouraged all national schools to offer religious classes (Omar \& Dan, 2007). Thus, religion is regarded as very important part of life of a Malaysian. It is important therefore to fill the gap in the literature by looking at religiosity as an important variable in Malaysian context as Malaysia has such uniqueness in the setting of religion. This study has thus contributed timely to the recent call by Hassan, Dollard \& Winefield (2010) to examine the role of religiosity in relation to the work-family interface.

In sum, the research needs as identified above represent the challenges which the present study attempt to address. The following conceptual model of work-family interface (see figure 1) is proposed in the current study and to address the important research problem of whether religiosity moderates the relationship of work-family interface on job satisfaction and family satisfaction.

\section{Development of Propositions}

Work-family interface is best characterized by two bi-directional dimensions of work-family interface which consists of work-family conflict (WFC) and family-work conflict (FWC) as well as work-family enrichment (WFE) and family-work enrichment (FWE) (Grzywacz \& Marks, 2000).

Research has shown that work-family conflict is related to a decreased in satisfaction, including job satisfaction and family satisfaction (Bedeian, Burke, \& Moffett, 1989; Hsu, 2011; Netemeyer, Boles, \& McMurrian, 1996; Perrone, Aegisdottir, Webb, \& Blalock, 2006). Specifically, work-to-family conflict has been shown to relate negatively to family satisfaction and family-to-work conflict has been shown to relate negatively to job satisfaction (Bedeian et al., 1989; Lapierre, Spector, Allen, Poelmans, Cooper, O’Driscoll, Sanchez, Brough, \& Kinnunen, 2008). Besides, Allen et al. (2000) also found a negative relationship between job satisfaction and work-to-family conflict and family-to-work conflict. Thus, the following propositions are suggested regarding the nature of these relationships.

Proposition 1a: Work-to-family conflict will negatively influence job satisfaction.

Proposition $1 b$ : Family-to-work conflict will negatively influence job satisfaction.

Proposition 2a: Work-to-family conflict will negatively influence family satisfaction.

Proposition 2b: Family-to-work conflict will negatively influence family satisfaction.

On the other hand, research has shown that WFE is positively related to job satisfaction (Aryee et al., 2005; Balmforth \& Gardner, 2006; Boyar \& Mosley, 2007) and FWE is positively related to family satisfaction (Hill, 2005; Wayne et al., 2006). Greenhaus and Powell (2006) hypothesized that psychological and physical resources in one role can improve the quality of life in another role. Research has also shown that positive experiences in the role of spouse or parents reduced job stress and psychological distress (Barnett, 1994). In addition, Perrone (1999) indicated that people who have rich combination of life roles such as work, marital and parental roles would experience greater overall life satisfaction than people who focus primarily on a single role. Thus, the following propositions regarding the nature of these relationships are expected:

Proposition 3a: Work-to-family enrichment will positively influence job satisfaction.

Proposition 3b: Family-to-work enrichment will positively influence job satisfaction.

Proposition $4 a$ : Work-to-family enrichment will positively influence family satisfaction.

Proposition $4 b$ : Family-to-work enrichment will positively influence family satisfaction.

Religiosity refers to the quality or extent to which a person is religious. Research has shown that higher levels of religiosity lower levels of depression, higher level of positive effect, less emotional distress and greater life satisfaction (Ellison et al., 1989; Levin et al., 1995; Pargament, et al., 2000; Fiala et al., 2002; Cole et al., 2008). Research has also shown that most people reporting high levels of religiosity are more likely to feel supported and have higher levels of well-being (Hill \& Pargament, 2003). Some other studies have shown that certain dimensions of religious and spiritual dimensions such as meaning making, meditation, and sense of mission relate positively to job satisfaction, job involvement, and productivity (Garcia-Zamor, 2003; Millman, Czaplewski, \& Ferguson, 2003). Robert, Young \& Kelly (2006) in their quantitative study also found that 
spiritual and religious well-being is positively related to job satisfaction. Lewis and Hardin (2002) in their studies found that a majority of businesspeople believes that their religious values can play an important role in their business decisions and career values.

Besides, studies also show that religious involvement is associated with attitudes about family and shape how men and women invest their time and their roles as husband or wife and father or mother. As an example, one common teaching of American religious institutions is that family is the central unit of social order and that family life should be governed by religious moral imperatives (Sherkat \& Ellison, 1999; Wilcox et al., 2004). Edgell (2005) found that across religious traditions, congregational leaders still encourage members to spend less time at work and more time with family and to reject the careerism and materialism that lead to overwork. Moreover, research has shown that higher level of religiosity could help one to cope with various life stressors, and result in decreased negative consequences such as depression, and have a positive effect on life satisfaction (Fiala et al., 2002; Hill \& Pargament, 2003). Thus, the following propositions regarding the nature of these relationships are expected:

Proposition 5: Religiosity will moderate the relationship between work-family interface and satisfaction. More specifically,

Proposition 5a: Religiosity will moderate the relationship between work-family conflict and job satisfaction.

Proposition 5b: Religiosity will moderate the relationship between work-family conflict and family satisfaction.

Proposition 5c: Religiosity will moderate the relationship between work-family enrichment and job satisfaction.

Proposition $5 d$ : Religiosity will moderate the relationship between work-family enrichment and family satisfaction.

\section{Method}

A deductive research approach using quantitative methodology will be adopted for this study. According to Kim (1993), quantitative studies are all about quantifying relationships between variables. In cross-sectional studies, variables of interest in a sample of subjects are assayed once and the relationships between them are determined. The main objectives of the present study are to examine the relationship between work-family interface and job and family satisfaction as well as to see the moderating role of religiosity on these relationships through a series of theoretically justified research hypothesis. Thus, a field survey adopted a cross-sectional design would be the most appropriate.Survey that utilises questionnaire is an effective tool to get opinions, attitudes, and descriptions as well as cause-and-effect relationship (Ghauri \& Gronhaug, 2002).

This study will use Structural Equation Modeling (SEM) as the analytical technique of choice for testing hypothesized relationship. The structural equation modeling (SEM) is chosen to analyze the data because it is a popular statistical technique used by empirical journal articles in the social sciences to test the relationships of independent and dependent variables (Cheng, 2001). It is also a powerful statistical tool capable of redesigning the proposed relationships in the hypothesized model to form several nested models and is more effective in finding the "best fitting" model to the data as suggested by the modification indexes (Cheng, 2001; Kline, 2005). SEM is therefore clearly advantageous in comparison with many conventional techniques which could only test a single relationship at one time.

Since many work-family studies involved in testing theoretical model, SEM has been used more often in work-family studies than in management research (Casper et al., 2007).Moreover, the SEM also excels beyond multiple regression, which is a popular statistical technique to test the relationships of independent and dependent variables, in expanding the explanatory ability and statistical efficiency for parsimonious model testing with a single comprehensive method (Cheng, 2001). Therefore, SEM is particularly effective to test the hypothesized model in this study that consists of multiple paths to be analyzed with moderating variables, and contain latent constructs such as work-family enrichment, work-family conflict, job satisfaction and family satisfaction and religiosity, that are being measured with multiple indicators.

The population for the study consists of full time employees of all three to five stars hotels in Sarawak registered under the membership directory of Malaysian Association of Hotels. Part-time employees will not form part of the study on the basis that many part-time employees think that they are outsiders (Alexandrov, Babakus, \& Yavas, 2007), and they do not stay at work as long as full-time employees do (Stamper \& Van Dyne, 2001). One and two stars hotels in Sarawak were not invited to participate in the study as hotel employees of these ratings 
are not professionally trained and the operations of hotels are not as complex as those from three to five stars rating.

\section{Potential Contributions}

This study has the potential to contribute at least in the following three aspects.

\subsection{Theoretical}

There has been a proliferation of research on work-family conflict. Recently, the research in this area has begun to shift paradigms in order to explore how work and family domains enrich each other. There is a dearth of empirical research pertaining to the antecedents and consequences of work-family facilitation and family-work facilitation (Aryee et al., 2005; Frone, 2003; Kinnunen et al., 2006). This is also valid in the tourism and hospitality literature (Mulvaney et al., 2007). Therefore, an investigation of the antecedents and consequences of two directions of conflict and enrichment grounded in the scarcity and expansion-enhancement perspectives can delineate a comprehensive picture of the work-family interface. Following the suggestions by many researchers such as Barnett (1998), Grzywacz et al. (2002), Frone (2003) and Lu et al. (2009), this study adds to the work-family literature by looking at both positive and negative side of work-family interface.

In addition, the present study is a pioneering attempt to understand religiosity as moderator on the relationship between work-family interface and job and family satisfaction. As mentioned earlier, there has been little attempt to study the relationship between work-family enrichment and job and family satisfaction. While the extent literature has explored models addressing work-family conflict and work-family enrichment separately, little is known about how all these variables fit together as part of a more comprehensive model. By creating a more holistic model of work-family interface, relevant variables can be examined in greater detail. Therefore, this study will merge and integrate work-family, job and family satisfaction and religiosity literature through examining the moderating effects of religiosity on the relationship between work-family enrichment and conflict, and satisfaction.

\subsection{Empirical}

The overwhelming majority of the empirical studies on the issues of both directions of conflict and facilitation have been made using samples derived from the developed Western or affluent countries (Aryee et al., 2005). Much of the current knowledge regarding the conflicts and enrichment in the work-family interface is based largely on the samples derived from the United States. This study will provide further empirical evidence and validates the theories and models of work-family using a sample of hotels in Malaysia.

In addition, the study will examine the relationship between work-family interface and job and family satisfaction. Frone et al. (1992a) proposed that job satisfaction and family satisfaction are affected by resources and stressors from other roles. Stressors and demands within one role create conflict with other roles, which in turn reduce satisfaction within those other roles. Under this framework, as seen in Figure 1, FWC and FWE is a proximal predictor of job satisfaction, whereas WFC and WFE is a proximal predictor of family satisfaction. WFC has been examined in a number of studies as a factor influencing job, family, and overall life satisfaction outcomes. It can reasonably be expected that as WFC and FWC increase, satisfaction in the work and family domains will decrease. This expectation has been supported by findings from a variety of samples showing a negative correlation between WFC and job and family satisfaction (Kossek \& Ozeki, 1998; Allen et al., 2000).

Lastly, religiosity will be examined as possible moderator between work-family interface and satisfaction (i.e. job satisfaction and family satisfaction). Very few studies have in fact viewed religiosity as a moderator of relationships between work and family role pressures and individual well-being (Ellison, 1991; Pargament, 1997). This study will thus provide empirical evidence on the relationships between these variables.

\subsection{Practical}

This study is important as it provides better understanding on the relationships among the interdependencies of the work-family interface. As indicated by Deputy Prime Minister and the Minister of Women, Family \& Community Development during the women summit 2009, striking a balance between home and work is no longer a women's issue but also for men. Thus, at the individual level, understanding the benefits of combining work and family will assist men and women in their quests for greater satisfaction in different life domains such as work and family.

In addition, this study is practically important because of the striking demographic shift in the workforce and the revolutionary changes in the organization. Understanding of these relationships will provide implications for employers to attract and retain the most capable human resources. Furthermore, it will also help employers to 
understand how to cultivate greater job satisfaction among their employees and improve individual and organizational performance. The findings of this study can delineate important management implications for the development and implementation of effective work-family balance strategies. This study will provide implications for the way that the hospitality industry views the outcomes of the work and family relationship. Rather than viewing family-friendly practices as a liability, hoteliers should recognize that these practices have potential strategic advantages for them with regards to job satisfaction and major industry problems such as turnover.

Furthermore, this study also attempts to give insight to policy maker on family issue such as increase in divorce rate that leads to single parent family and social issue such as increase in depression and suicide rate. Specifically, this study will be among the few that provide important empirical evidence to answer the call by the Deputy Prime Minister Tan Sri Muhyiddin Mohd Yassin (Women Summit 2009) where more research needs to be done to improve work life balance for working Malaysians.

\section{Conclusion}

In sum, the central contribution of this paper is to propose a conceptual model to examine the relationship between work-family interface and job and family satisfaction in the context of hospitality industry. Besides, this paper also discusses the development of the relevant propositions as suggested by the relevant theories and past literature. The propositions provide the mechanism to test whether the hypothesized model of this study fits the data to be collected. The major theoretical, empirical and practical contributions of this study has also been highlighted and discussed.

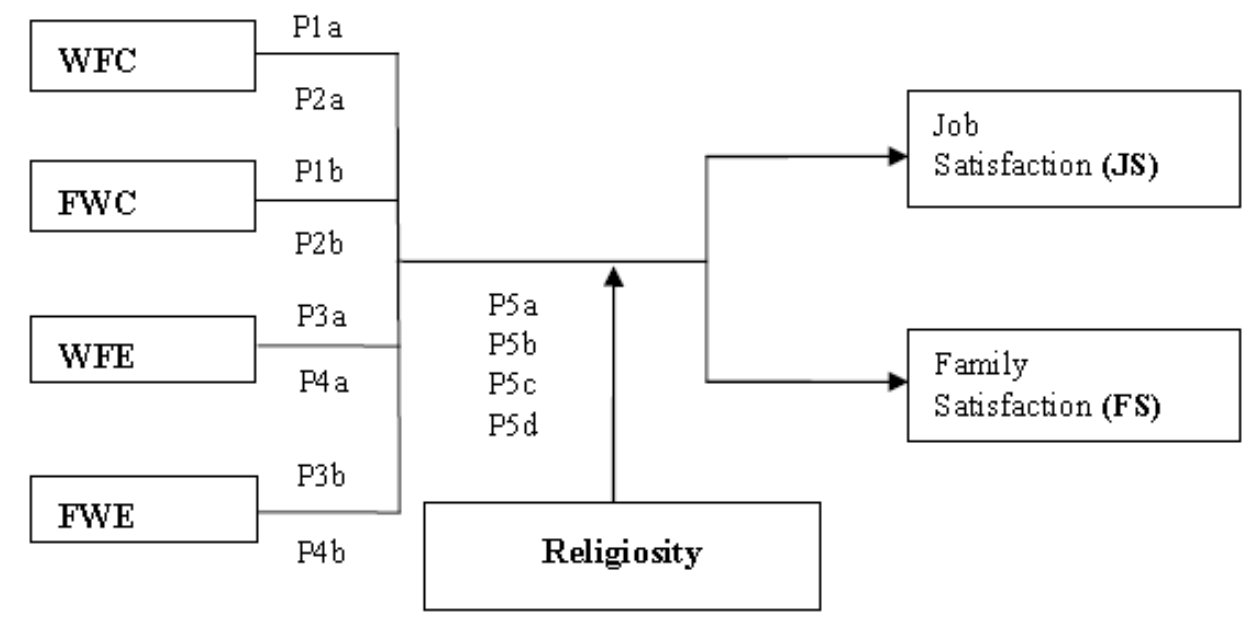

Figure 1. The proposed conceptual model

\section{References}

Abdullah, A. (1994). Leading the motivating the Malaysian workforce. Malaysian Management Review, 29(3), $82-101$.

Abdullah, A. (1996). Going glocal: Cultural dimensions in Malaysian management. Kuala Lumpur: Malaysian Institute of Management.

Alexandrov, A., E. Babakus, \& U. Yavas. (2007). Theeffects of perceived management concern for front line employees and customers on turnover intentions: Moderating role of employment status. Journal of Service Research, 9(4), 356-371. http://dx.doi.org/10.1177/1094670507299378

Allen, T.D., Herst, D.E., Bruck, C.S., \& Sutton, M. (2000). Consequences associated with work-to-family conflict: A review and agenda for future research. Journal of Occupational Health Psychology, 5, 278-308. http://dx.doi.org/10.1037/1076-8998.5.2.278

Amin, S., \& Alam, I. (2008). Women's employment decisions in Malaysia: Does religion matter? Journal of Socio-Economics, 37, 2368-2379. http://dx.doi.org/10.1016/j.socec.2008.04.012

Aryee, S., Srinivas, E. S., \& Hwee Hoon Tan. (2005). Rhythms of life: Antecedents and outcomes of work-family balance in employed parents. Journal of Applied Psychology, 90, 132-146. http://dx.doi.org/10.1037/0021-9010.90.1.132 
Balmforth, K., \& Gardner, D. (2006). Conflict and facilitation between work and family: Realizing the outcomes for organizations. New Zealand Journal of Psychology, 3, 69-76.

Barnett, R. C. (1994). Home-to-work spillover revisited: A study of full-time employed women in dual-earner couples. Journal of Marriage and the Family, 56, 647-656. http://dx.doi.org/10.2307/352875

Barnett, R. C. (1998). Toward a review and reconceptualization of the work/family literature. Genetic, Social, and General Psychology Monographs, 124, 125-182.

Bedeian, A.G., Burke, B. G., \& Moffett, R.G. (1989). Outcomes of work-family conflict among married male and female professionals. Journal of Management, 14(3), 475-491. http://dx.doi.org/10.1177/014920638801400310

Boyar, S.L. \& Mosley, D.C. (2007). The relationship between core self-evaluations and work and family satisfaction: The mediating role of work-family conflict and facilitation. Journal of Vocational Behavior, 71, 265-281. http://dx.doi.org/10.1016/j.jvb.2007.06.001

Cascio, W.F. (2003). Changes in worker, work, and organizations. In W.C. Borman \& D.R. Ilgen (Eds.), Handbook of psychology: Industrial and organizational psychology (Vol. 12, pp. 401-422). New York: Wiley.

Casper, W., Eby, L. T., Bordeaux, C., Lockwood, A., \& Burnett, D. (2007). A review of methods in IO/OB work-family research. Journal of Applied Psychology, 92(1), 28-43. http://dx.doi.org/10.1037/0021-9010.92.1.28

Cheng, W.L. (2001). SEM being more effective than multiple regression in parsimonious model testing for management development research. Journal of Management Development, 20(7), 650-667. http://dx.doi.org/10.1108/02621710110400564

Cole, B.S., Hopkins, C.M., Tisak, J., Steel, JL., \& Carr, B.I. (2008). Assessing spiritual growth and spiritual decline following a diagnosis of cancer: reliability and validity of the spiritual transformation scale. Psycho-oncology, 17(2), 112-121. http://dx.doi.org/10.1002/pon.1207

Dermody, M., \& R. Holloway. (1998). Recruitment and Retention of Managers. Cornell Hotel and Restaurant Administration Quarterly, 39(6), 20-25.

Duxbury, L. E., \& Higgins, C. A. (1991). Gender differences in work-family conflict. Journal of Applied Psychology, 76(1), 60-74. http://dx.doi.org/10.1037/0021-9010.76.1.60

Eby, L., \& Allen, T. (1998). Perceptions of Relocation Services in Relocation Decision-Making: An Exploratory Field Study. Group and Organization Management, 23, 447-469. http://dx.doi.org/10.1177/1059601198234006

Eder, R., \& C. Lundberg. (1990). "Paying Your Dues" in the Hospitality Industry: How Functional is the Belief? Hospitality Research Journal, 14, 363-369.

Edgell, P. (2005). Religion and family in a changing society. Princeton, NJ: Princeton University Press.

Ellison, C. G. (1991). Religious involvement and subjective well-being. Journal of Health and Social Behavior, 32, 80-99. http://dx.doi.org/10.2307/2136801

Ellison, C.G., Gay, D. A., \& Glass, T. A. (1989). Does religious commitment contribute to individual life satisfaction? Social Forces, 68, 100-123.

Fiala, W. E., Bjorck, J. P., \& Gorsuch, R. (2002). The Religious Support Scale: Construction, validation, and cross validation. American Journal of Community Psychology, 30, 761-786. http://dx.doi.org/10.1023/A:1020264718397

Friedman, S. D., \& Greenhaus, J. H. (2000). Work and families--allies or enemies?: What Happens when business professionals confront life choices. New York: Oxford University Press.

Frone, M. R., Russell, M., \& Cooper, M. L. (1992). Antecedents and outcomes of work-family conflict: testing a model of the work-family interface. Journal of Applied Psychology, 77, 65-78. http://dx.doi.org/10.1037/0021-9010.77.1.65

Frone, M. R. (2003). Work-family balance. In J. C. Quick \& L. E. Tetrick (Eds.), Handbook of occupational health psychology (pp. 143-162). American Psychological Association. Washington, DC. http://dx.doi.org/10.1037/10474-007 
Garcia-Zamor, J. C. (2003). Workplace spirituality and organizational performance. Public Administration Review, 63, 355-363. http://dx.doi.org/10.1111/1540-6210.00295

Ghauri, P., \& Gronhaug. (2002). Research methods in business studies ( $2^{\text {nd }}$ ed.). Great Britain: Pearson Education Limited.

Greenhaus, J. H., \& Powell, G. N. (2006). When work and family are allies: A theory of work-family enrichment. Academy of Management Review, 31, 72-92. http://dx.doi.org/10.5465/AMR.2006.19379625

Grzywacz, J.G., \& Marks, N.F. (2000). Reconceptualizing the work-family interface: an ecological perspective on the correlates of positive and negative spillover between work and family. Journal of Occupational Health Psychology, 5(1), 111-26. http://dx.doi.org/10.1037/1076-8998.5.1.111

Grzywacz, J. G., Almeida, D.M., \& McDonald, D.A. (2002). Work-family spillover and daily reports of work and family stress in the adult labor force. Family Relations, 51, 28-36. http://dx.doi.org/10.1111/j.1741-3729.2002.00028.x

Hassan, Z., Dollard, M.F., \& Winefield, A.H. (2010). Work-family conflict in East vs Western countries. Cross $\begin{array}{lllll}\text { Cultural Management: } \quad \text { An International Journal, } & \text { 17(1), }\end{array}$ http://dx.doi.org/10.1108/13527601011016899

Hill, E. J. (2005). Work-family facilitation and conflict, working fathers and mothers, work-family stressors and support. Journal of Family Issues, 26, 793-819. http://dx.doi.org/10.1177/0192513X05277542

Hill, P. C., \& Pargament, K. L. (2003). Advances in the conceptualization and measurement of religion and spirituality: Implications for physical and mental health research. American Psychologist, 58, 64-74. http://dx.doi.org/10.1037/0003-066X.58.1.64

Hofstede, G. (2001). Culture's consequences: Comparing values, behaviors, institutions, and organizations across nations $\left(2^{\text {nd }}\right.$ ed.). Thousand Oaks, CA: Sage.

Hsu, Y.R. (2011). Work-family conflict and job satisfaction in stressful working environments: The moderating roles of perceived supervisor support and internal locus of control, International Journal of Manpower, 32(2), 233-248. http://dx.doi.org/10.1108/01437721111130224

Kennedy, D., \& M. Fulford. (1999). On the move: Management Relocation in the Hospitality Industry. Cornell Hotel and Restaurant Administration Quarterly, 40, 2, 60-68.

Kinnunen, U., Feldt, T., Geurts, S., \& Pulkkinen, L. (2006). Types of work-family interface: well-being correlates of negative and positive spillover between work and family. Scandinavian Journal of Psychology, 47(2), 149-162. http://dx.doi.org/10.1111/j.1467-9450.2006.00502.x

Kline, R.B. (2005). Principles and practice of structural equation modeling (2nd ed.). NewYork: The Guilford Press.

Kossek, E.E., \& Ozeki, C. (1998). Work-family conflict, policies, and the job-life satisfaction relationship: A review and directions for organizational behavior-human resources research. Journal of Applied Psychology, 83(2), 139-149. http://dx.doi.org/10.1037/0021-9010.83.2.139

Lapierre, L.M., Spector, P.E., Allen, T.D., Poelmans, S., Cooper, C.L., O’Driscoll, M.P., ... Kinnunen, U. (2008). Family-supportive organization perceptions, multiple dimensions of work-family conflict, and employee satisfaction: A test of model across five samples. Journal of Vocational Behavior, 73, 92-106. http://dx.doi.org/10.1016/j.jvb.2008.02.001

Levin, J. S., Chatters, L. M., \& Taylor, R. J. (1995). Religious effects on health status and life satisfaction among Black Americans. Journal of Gerontology (Social Sciences), 50B, S154-S163. http://dx.doi.org/10.1093/geronb/50B.3.S154

Lewis, M. M., \& Hardin, S. I. (2002). Relations among and between career values and Christian religious values. Counseling and Values, 46, 96-107. http://dx.doi.org/10.1002/j.2161-007X.2002.tb00280.x

Lu, J.F., Siu, O.L., Spector, P. E., \& Shi, K. (2009). Antecedents and outcomes of a fourfold taxonomy of work-family balance in Chinese employed parents. Journal of Occupational Health Psychology, 14(2), 182-192. http://dx.doi.org/10.1037/a0014115

Lu, L., \& C. Cooper. (1990). Stress of Job Relocation: Progress and Prospect. Work and Stress, 4, 121-128. http://dx.doi.org/10.1080/02678379008256974 
Lobel, S.A. (1991). Allocation of investment in work and family roles: Alternative theories and implications for research. Academy of Management Review, 16, 507-521.

Martin, R. (1999). Adjusting to Job Relocation: Relocation Preparation Can Reduce Relocation Stress. Journal of Occupational and Organizational Psychology, 72, 231-235. http://dx.doi.org/10.1348/096317999166626

Miilman, J., Czaplewski, A. J., \& Ferguson, J. (2003). Workplace spirituality and employee work attitudes: An exploratory empirical assessment. Journal of Organizational Change Management, 16, 426-447. http://dx.doi.org/10.1108/09534810310484172

Mulvaney, R. H., O’Neill, J. W., Cleveland J. N., \& Crouter, A. C. (2007). A model of work-family dynamics for hotel managers. Annals of Tourism Research, 34, 66-87. http://dx.doi.org/10.1016/j.annals.2006.07.002

Munck, B. (2001). Changing a culture of face time. Harvard Business Review, 79, 125-131.

Near, J. P., Smith, C. A., Rice, R. W., \& Hunt, R. G. (1984). A comparison of work and nonwork predictors of life satisfaction. Academy of Management Journal, 27(1), 184-190. http://dx.doi.org/10.2307/255966

Netemeyer, R.G., Boles, J.S., \& McMurrian, R. (1996). Development and validation of work-family conflict and family-work conflict scales, Journal of Applied Psychology, 81(4), 400-410. http://dx.doi.org/10.1037/0021-9010.81.4.400

Noor, N.M. (1999). Roles and women's well-being: Some preliminary findings from Malaysia. Sex Roles, 41(314), 123-145. http://dx.doi.org/10.1023/A:1018846010541

Noor, N.M. (2008). Work and women's well being: Religion as age as moderators. Journal of Relig Health, 47, 476-490. http://dx.doi.org/10.1007/s10943-008-9188-8

Omar, N., \& Dan, C. (2007). Race, gender and religion within the construct of 'Bangsa Malaysia' and 'National Islamic Identity' in Malaysian literature. Journal of English Studies and Comparative Literature, 9(1), 44-54.

Pargament, K. (1997). The psychology of religion and coping: Theory, research, and practice. New York: Guilford Press.

Pargament, K., Koenig, H., \& Perez, L. (2000). The many methods of religious coping: Development and initial validation of the RCOPE. Journal of Clinical Psychology, 56, 519-543. http://dx.doi.org/10.1002/(SICI)1097-4679(200004)56:4<519::AID-JCLP6>3.0.CO;2-1

Perrone, K. M. (1999). Balancing life roles to achieve career happiness and life satisfaction. Career Planning and Adult Development Journal, 15, 49-58.

Perrone, K.M., Aegisdottir, S., Webb, L.K., \& Blalock, R.H. (2006). Work-family interface: Commitment, conflict, coping, and satisfaction. Journal of Career Development, 32(3), 286-300. http://dx.doi.org/10.1177/0894845305283002

Rice, R. W., McFarlin, D. B., Hunt, R. G., \& Near, J. P. (1985). Organizational work and the perceived quality of life: Toward a conceptual model. Academy of Management Review, 10(3), 296-310.

Robert, T.E., Young, J.S., \& Kelly, V.A. (2006). Relationships between adult workers' spiritual well-being and job satisfaction: A preliminary study. Counseling and Values, 50(3), 165-175. http://dx.doi.org/10.1002/j.2161-007X.2006.tb00053.x

Schultheiss, D.E. (2006). The interface of work and family life. Professional Psychology: Research and Practice, 37(4), 334-341. http://dx.doi.org/10.1037/0735-7028.37.4.334

Schwartzberg, N.S., \& Dytell, R.S. (1996). Dual-earner families: The importance of work stress and family stress for psychological well-being. Journal of Occupational Health Psychology, 1(2), 211-223. http://dx.doi.org/10.1037/1076-8998.1.2.211

Schein, E. H. (1984). Culture as an environmental context for careers. Journal of Occupational Behavior, 5, 71-81. http://dx.doi.org/10.1002/job.4030050107

Sherkat, D., \& Ellison, C. (1999). Recent developments and current controversies in the sociology of religion. Annual Review of Sociology, 25, 363-394. http://dx.doi.org/10.1146/annurev.soc.25.1.363

Stalcup, L., \& T. Pearson. (2001). A Model of the Causes of Management Turnover in Hotels. Journal of Hospitality and Tourism Research, 25, 17-30. http://dx.doi.org/10.1177/109634800102500103

Stamper, C. L., \& L. Van Dyne. (2001). Work status and organizational citizenship behavior: A field study of restaurant employees. Journal of Organizational Behavior, 22(5), 517-536. http://dx.doi.org/10.1002/job.100 
Wayne, J., Randel A, \& Stevens J. (2006). The role of identity and work-family support in work-family enrichment and its work-related consequences. Journal of Vocational Behavior, 69, 445-461. http://dx.doi.org/10.1016/j.jvb.2006.07.002

Wilcox, W. B., Chaves, M., \& Franz, D. (2004). Focused on the family? Religious traditions, family discourse, and pastoral practice. Journal for the Scientific Study of Religion, 43(4), 491-504. http://dx.doi.org/10.1111/j.1468-5906.2004.00251.x

Women's Summit Report. (2009). The Ministry of Women, Family \& Community Development, Malaysia. Retrieved March 15 , 2010 , from http://www.kpwkm.gov.my/portal/BI/Upload/20090306_003917_18026_Laporan\%20Sidang\%20Kemunca k\%20Wanita\%202008.pdf

Yang, N., Chen, C.C., Choi, J., \& Zhou, Y. (2000). Sources of work-family conflict: A Sino-U.S. comparison of the effects of work and family demands. Academy of Management Journal, 43, 113-123. http://dx.doi.org/10.2307/1556390 